\title{
Relevance of Protein Content within the Renal Scaffold for Kidney Bioengineering and Regeneration
}

\author{
Fatima Guerrero ${ }^{1}$, Andres Carmona ${ }^{1}$, Rosa Ortega $^{1,2}$, Sagrario Cañadillas ${ }^{1,3}$, Rodolfo Crespo $^{4,5}$, \\ Concha Herrera ${ }^{1,3,5,6}$, Pedro Aljama ${ }^{1,4,5,7}$ \\ ${ }^{1}$ Maimonides Institute of Biomedical Research of Cordoba, Cordoba, Spain; ${ }^{2}$ Anatomical Pathology Service, Reina \\ Sofía University Hospital, Cordoba, Spain; ${ }^{3}$ Cellular Therapy Unit, Reina Sofía University Hospital, Cordoba, Spain; \\ ${ }^{4}$ Department of Nephrology, Nephrology Service, Reina Sofia University Hospital, Cordoba, Spain; ${ }^{5}$ University of \\ Cordoba, Cordoba, Spain; ${ }^{6}$ Hematology Departament, Reina Sofía University Hospital, Cordoba, Spain; ${ }^{7}$ RETICs Red \\ Renal, Instituto de Salud Carlos III, Madrid, Spain
}

Correspondence to: Fatima Guerrero, fatima.guerrero@imibic.org Keywords: Bioengineering, Kidney, Decellularization, Scaffold, Proteomic Received: September 29, $2017 \quad$ Accepted: November 26, $2017 \quad$ Published: November 29, 2017

Copyright $\odot 2017$ by authors and Scientific Research Publishing Inc.

This work is licensed under the Creative Commons Attribution International License (CC BY 4.0).

http://creativecommons.org/licenses/by/4.0/

\section{(c) (1) Open Access}

\section{ABSTRACT}

Chronic kidney disease is currently a major public health problem around the world. Although hemodialysis increases survival of patients with end-stage renal disease, kidney transplantation remains the only potentially curative treatment. However, transplantation as a therapeutic option is limited by availability of suitable donor organs. This situation highlights the urgent need to find new and potentially inexhaustible sources of transplantable organs. Perfusion decellularizarion of whole organs is a novel approach to organ engineering and regeneration. In the present research, we used a continuous perfusion decellularization protocol to eliminate cellular componet of kidney and evaluated residual scaffold components after decellularizarion process by proteomics analysis. Our proteomic data show that this protocol results in incomplete removal of cellular proteins. However, unlike other authors, we assume that proteins retained within decellularized kidney scaffold could be the basis for specific homing and celular differentation in the recellularization process.

\section{INTRODUCTION}

Chronic kidney disease (CKD) is currently a major public health worldwide problem $[1,2]$. CKD affects a significant percentage of the population; mainly due to that their leading causes are highly prevalent disorders such as aging, hypertension, diabetes and vascular disease [3]. Although hemodialysis increases survival of patients with end-stage renal disease (ESRD), the kidney transplantation remains the only po- 
tentially curative treatment [4]. Because of this, the demand for suitable organs for transplantation has reached a level that far exceeds supply. This disparity has greatly to a wide waiting list. These data highlight the urgency to find new and potentially inexhaustible sources of transplantable organs.

Tissue engineering and regenerative medicine arise as a promising solution for the treatment of kidney disease through the development of renal structures with normal function by bioengineering. Recent advances in this area, involving decellularization of native organs and further recellularization of the resulting extracellular matrix (ECM), have provided a hopeful approach for the production of transplantable organs [5-10].

Kidney decellularization has been successfully achieved using a variety of approaches and protocols. Currently, the most efficient technique that allows decellularization of complete organs is the chemical perfusion. Sodium dodecyl sulfate (SDS) and non-ionic detergent Triton X-100, are the most frequently used agents for tissue decellularization [5, 11-14]. These agents allow complete removal of cellular material, preserving the three-dimensional ECM and vascular network within the organ.

Criteria to evaluate the effectiveness of the decellularization process are mainly based on structural and content details of the ECM scaffold by both histological and biochemical analysis. However, recent observations underwrite that decellularized scaffolds still contain many cellular protein and proteomic analysis would provide crucial characterization of the decellularization process to create scaffolds biocompatible, nontoxic and suitable for its subsequent recellularization [15].

In this research, our aims were 1) to develop decellularization protocol by detergent perfusion that effectively removes all cellular components of the kidney and 2) to assess the changes in the proteome after decellularization process.

\section{METHODS}

\subsection{Harvesting of Rat Kidneys}

All experimental protocols were reviewed and approved by the Ethics Committee for Animal Research of the University of Cordoba, and all rats received humane care in compliance with the guiding principles in the Guide for the Care and Use of Laboratory Animals.

The animals were sacrificed by exsanguination under general anaesthesia (i.p. sodium thiopental). After a median laparotomy and systemic heparinization through the infrahepatic inferior vena cava for anticoagulation, renal artery, renal vein and ureter were complety isolated. Subsequently, the whole kidney was harvested and transferred to a cell culture dish. The whole kidney was maintained hydrated with cooled PBS while the main vasculature of the organ was cannulated.

\subsection{Whole-Organ Perfusion Decellularization}

We performed a decellularization protocol following the method used by Guyette J et al. [11], with minor modifications. Briefly, renal artery was cannulated with a 24-G cannula and fixed with 3/0 silk suture. The kidney was manually perfused with $10 \mathrm{ml}$ of diluted heparin (Sanofi, Gentilly, France) solution to remove residual blood. Then, the cannulated kidney was mounted into the decellularization chamber and was connected to the peristaltic pump (Fresenius-Kabi, Bad Homburg, Germany). The perfusión rate for each step was set at $0.4 \mathrm{~mL} / \mathrm{min}$. The decellularization process was initiated by perfusion with PBS for 30 minutes, followed by $0.66 \%$ SDS (Thermo Fisher Scientific, Waltham, MA, USA) in deionized water for 18 hours until organ translucency was confirmed. Finally, the kidney was perfused with $1 \%$ Triton X-100 (Acros Organics, Fisher Scientific) in deionized water for 30 minutes. Following decellularization, we washed the kidney scaffolds with PBS containing 10,000 U/mL penicillin G, $10 \mathrm{mg} / \mathrm{mL}$ streptomycin, and $25 \mu \mathrm{g} / \mathrm{mL}$ amphotericin-B (Sigma-Aldrich, St. Louis, MO, USA) at $0.4 \mathrm{~mL} / \mathrm{min}$ constant arterial perfusion for 96 hours. Wash solution was changed every 12 hours.

All used solutions were buffered at ph 7.4 and prepared under sterile conditions. The buffered solutions were kept to $4^{\circ} \mathrm{C}$ until used. 


\subsection{Visualization of the Vascular System}

To visualize the three-dimensional microvasculature in the scaffolds after decellularization, a blue colored solution was injected throught cannulated renal artery of the decellularized kidney. To performed the solution was used Commasie Brilliant Blue R (Sigma-Aldrich).

\subsection{Quantification of Residual Detergent}

Removal of SDS detergent of the kidney perfusate solution was quantified using the Stains All Dye reagent (Sigma-Aldrich) by absorbance readings at $438 \mathrm{~nm}$ as previously described by Rusconi $\mathrm{F}$ et al. [16].

\subsection{Basic Histology Assessment of the Kidney Scaffolds}

To assess cell and nuclear clearance as well as preservation of extracellular matrix, hematoxylin and eosin (H\&E) and silver methamine staining were performed in decellularized and native kidneys. Briefly, decellularized and native kidneys transverse sections were fixed in $4 \%$ formalin, dehydrated through a graded series of ethanol, and embedded in paraffin. Three-micrometer paraffin sections were stained with $\mathrm{H} \& \mathrm{E}$ and methenamine silver and examined by normal light microscopy.

\subsection{Protein Extraction and Digestion}

Protein lysates from native and decellularized kidney were prepared by homogenizing tissue in lysis buffer (7 M urea, 4\% CHAPS (w/v), 0.5 M DTT) containing protease inhibitor cocktail (Sigma-Aldrich) using a rotating blade homogenizator. Samples were cleaned by protein precipitation with TCA/acetone and solubilised in $50 \mu \mathrm{L}$ of $0.2 \%$ RapiGest SF (Waters, Milford, MA, USA) in $50 \mathrm{mM}$ ammonium bicarbonate. The total protein content was measured using the Qubit Protein Assay Kit (Thermo Fisher Scientific); $50 \mu \mathrm{g}$ of protein was subjected to trypsin digestion following a protocol adapted from Vowinckel et al. [17]. Briefly, protein samples were incubated with $5 \mathrm{mM} \mathrm{DTT}$ at $60^{\circ} \mathrm{C}$ for $30 \mathrm{~min}$ and then with $10 \mathrm{mM}$ iodoacetamide at room temperature and in darkness for $30 \mathrm{~min}$. Sequencing Grade Modified Trypsin (Promega, Madison, WI, USA) was added at a 1:40 trypsin:protein ratio and incubated at $37^{\circ} \mathrm{C}$ for 2 hours; the same amount of trypsin was again added and incubated at $37^{\circ} \mathrm{C}$ for another 15 hours. RapiGest was then precipitated by centrifugation after incubating with $0.5 \% \mathrm{TFA}$ at $37^{\circ} \mathrm{C}$ for 1 hour.

\subsection{Mass Spectrometry Analysis}

The peptide solutions were analysed by a shotgun data-dependent acquisition (DDA) approach using nano-LC-MS/MS. One $\mu \mathrm{g}$ of each pooled sample $(2 \mu \mathrm{L})$ was separated into a nano-LC system Ekspert nLC415 (Eksigent, Dublin, CA, USA) using an Acclaim PepMap C18 column $(75 \mu \mathrm{m} \times 25 \mathrm{~cm}, 3 \mu \mathrm{m}, 100$ $\AA$ ) (Thermo Fisher Scientific) at a flow rate of $300 \mathrm{nl} / \mathrm{min}$. Water and ACN, both containing $0.1 \%$ formic acid, were used as solvents A and B, respectively. The gradient run consisted of 5\% to $30 \%$ B for $120 \mathrm{~min}$.

Eluting peptides were directly injected into a hybrid quadrupole-TOF mass spectrometer Triple TOF 5600+ (Sciex, Redwood City, CA, USA) operated with a data-dependent acquisition system in positive ion mode. A NanoSpray III ESI source (Sciex) was used for the interface between nLC and MS, with an application of $2600 \mathrm{~V}$ voltage. The acquisition mode consisted of a $250 \mathrm{~ms}$ survey MS scan from 350 to 1250 $\mathrm{m} / \mathrm{z}$ followed by an MS/MS scan from 230 to $1700 \mathrm{~m} / \mathrm{z}$ (60 ms acquisition time, rolling collision energy) of the top 65 precursor ions from the survey scan, for a total cycle time of $4.2 \mathrm{~s}$. The fragmented precursors were then added to a dynamic exclusion list for $15 \mathrm{~s}$; any singly charged ions were excluded from the MS/MS analysis.

The peptide and protein identifications were performed using Protein Pilot software (version 5.0.1, Sciex) with a Rattus Swiss-Prot concatenated target-reverse decoy database (downloaded in May 2015), containing 7927 target protein sequences, specifying iodoacetamide as Cys alkylation. The false discovery 
rate (FDR) was set to 0.01 for both peptides and proteins.

\subsection{GO Analysis and Bioinformatic Tools}

The proteins identified in native and kidney scaffold were described using Uniprot knowledgebase (http://www.uniprot.org/). The list of gene names from each dataset was used to generate a Venn diagram (http://bioinformatics.psb.ugent.be/webtools/Venn/). Network analysis protein-protein interactions of the identified proteins were performed using STRING (https://string-db.org/). The confidence score for selection was 0.7. Gene ontology (GO) terms enrichment was calculated using Gene Ontology enRIchment anaLysis and visuaLizAtion (GOrilla) tool (http://cbl-gorilla.cs.technion.ac.il/). Significance for each GO term was assessed with p-values that were corrected using FDR q-value according to the Benjamini and Hochberg (1995) method.

\section{RESULTS}

\subsection{Kidney Decellularization}

In our laboratory, the continuous perfusion decellularization protocol was based on the combination of two detergents (SDS and Triton X-100). Detergent perfusion and washing of rat kidney was maintained with low and constant physiological perfusion pressures to allow gradual adaptation to changes in vascular resistance. As shown in the Figure 1(A) \& Figure 1(B), after decellularization of rat kidney, the scaffold
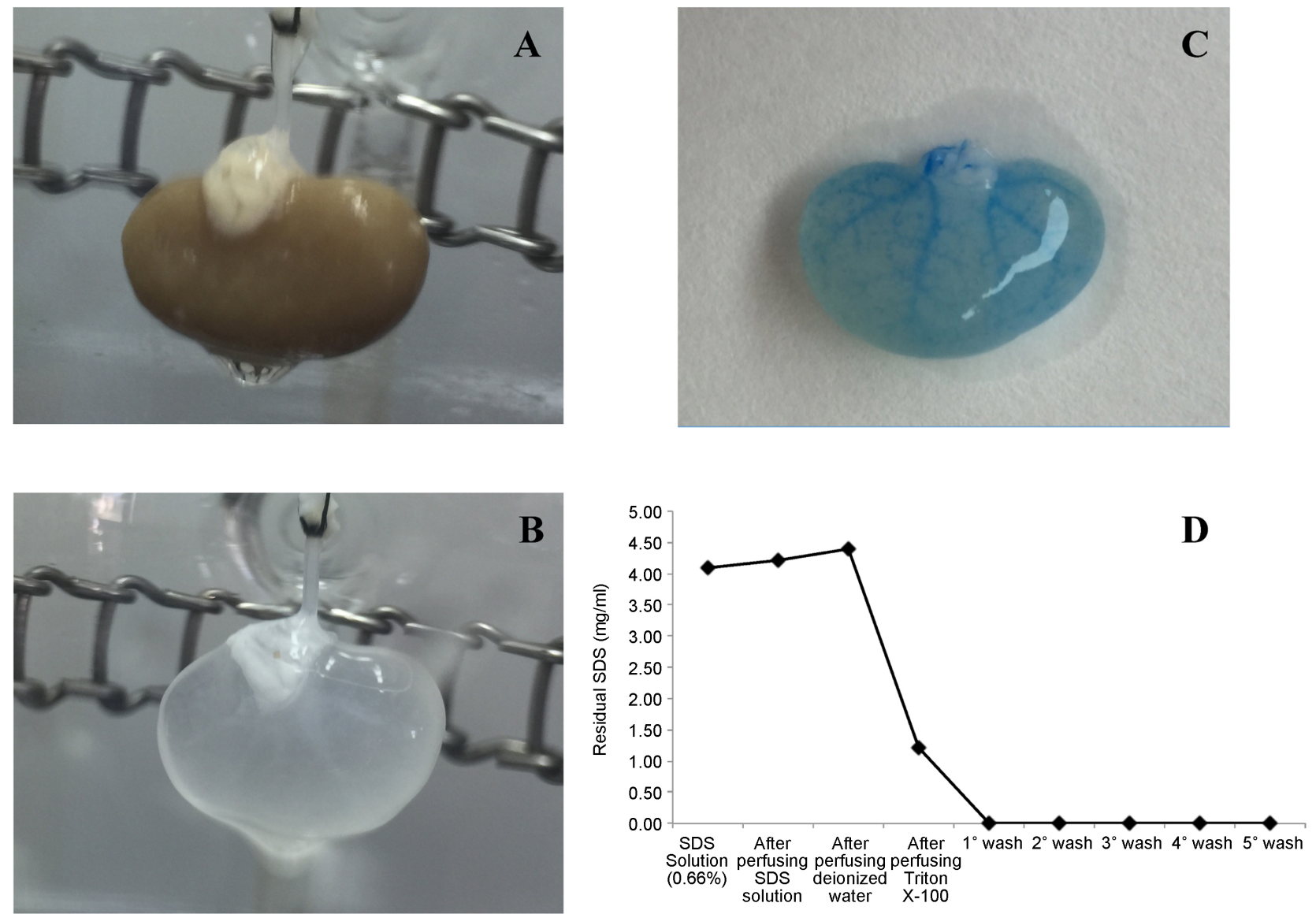

Figure 1. Representative pictures of kidney (A) before and (B) after decellularization process. Mean length of native and scaffold kidney was $1.8 \mathrm{~cm}$. (C) Visualizarion fo the vascular network. (D) SDS quantification in kidney perfusate solutions. 
retained overall shape and the macroscopic structure, and became white and translucent due to the removal of the cellular contents. Furthermore, the three dimensional structure of the vasculature was preserved and intact (Figure 1(C)).

According to previous studies, SDS perfusion shows severe cellular toxicity in subsequent recellularization processes $[11,18]$. Analysis of several samples of the perfusate solution during decellularization process confirmed removal of SDS detergent. After perfusing Triton-X100, we observed a marked decrease in the levels of SDS becoming undetectable in the washing process, suggesting complete removal of residual SDS (Figure 1(D)).

\subsection{Histological Characterization of the Rat Renal ECM Scaffold}

The microscopic examination revealed the renal scaffold microarchitecture preserved and the integrity of the glomerular, tubular and vascular structures. Histologic evaluation with H\&E staining showed pink eosinophilic structures typical of collagen fibrils, whereas no basophilic staining typical of cellular nuclear material was observed (Figure 2(E)), as compared to normal rat kidney staining (Figure 2(B)).

Moreover, methenamine silver staining was performed to assess preservation of basement membranes. Figure 2(F) showed the characteristic pattern (in black) of the glomerular and tubular basement membranes intact after the decellularization process and confirming successfully eliminate the cellular component compared to normal rat kidney staining (Figure 2(C)).

\subsection{Proteomic Analysis of the Kidney Scaffold}

The proteins identified in native and kidney scaffold were described using Uniprot knowledgebase (Data Supplementary). As expected, fewer distinct proteins were detected after decellularization process,
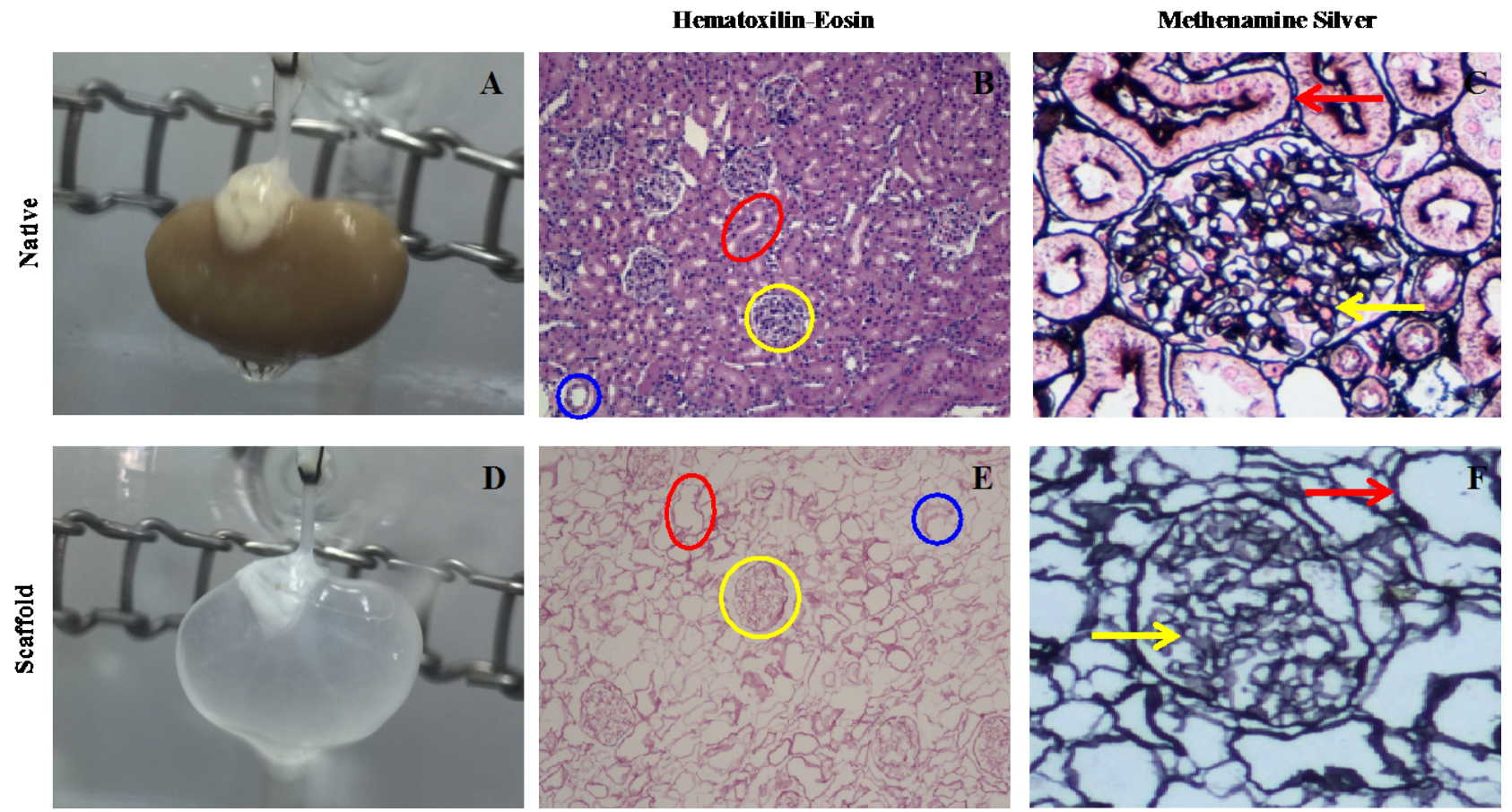

Figure 2. Histological analysis of renal scaffold. ((B), (E)) H\&E staining of native (B) versus decellularized kidney (E). Circles show glomerular (yellow), tubular (red) and vascular (blue) structures. ((C), (F)) Methenamine silver staining of native (C) versus decellularized kidney $(F)$. Arrows show glomerular (yellow) and tubular (red) basement membranes. 
dropping from 990 to 424 proteins identifications in the native and decellularized kidney respectively. As shown in the Venn Diagram (Figure 3(A)), of the total 424 proteins identified after decellularization

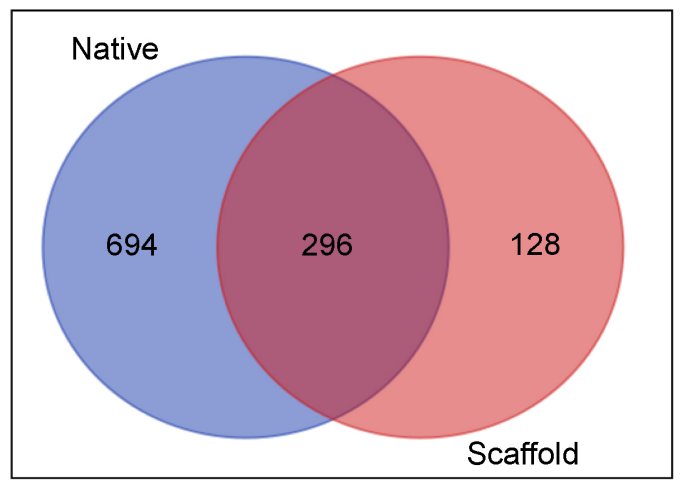

(A)

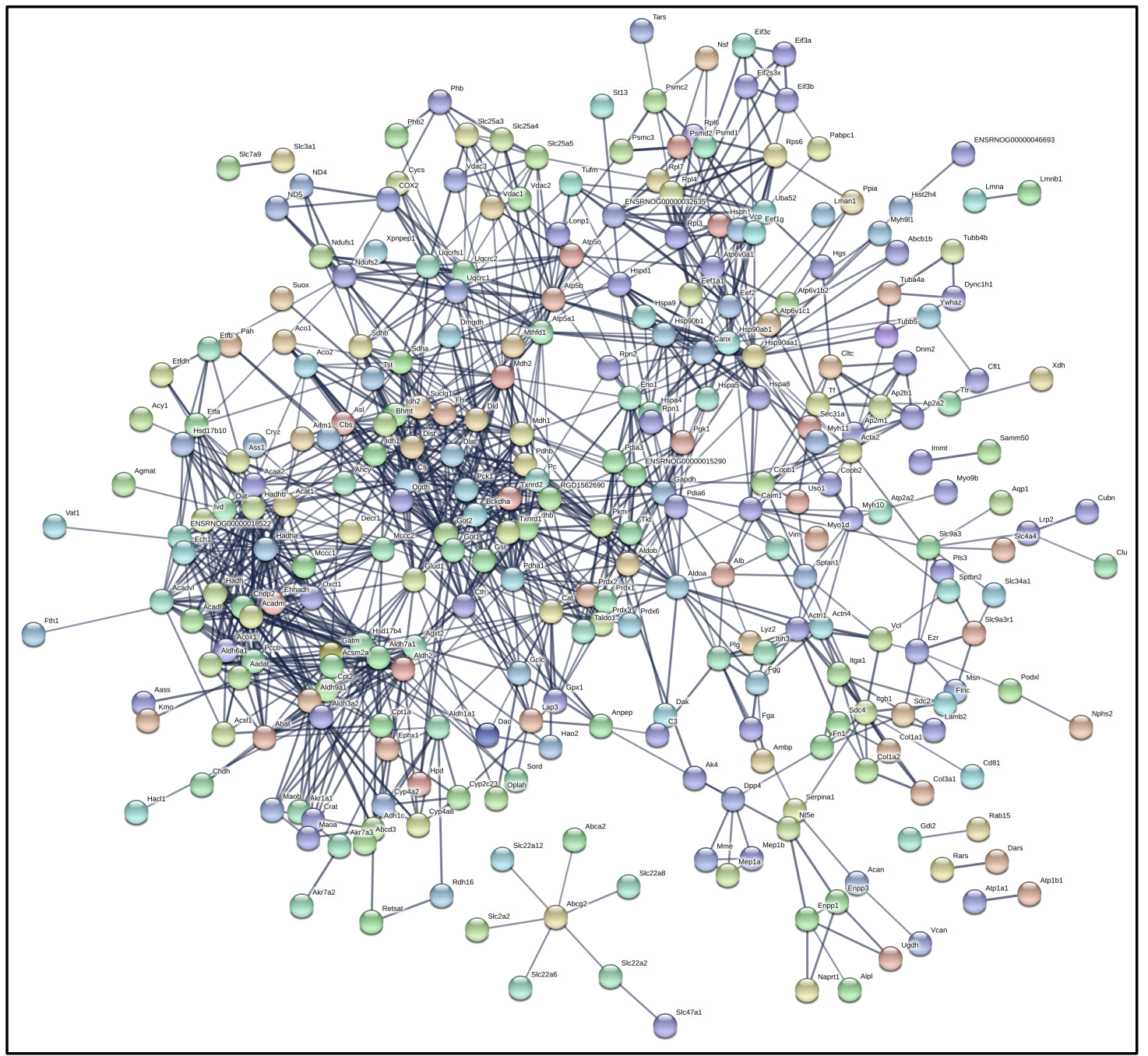

(B)

Figure 3. (A) Venn diagram with the number of protein identifications for native and decellularized kidney; (b) protein interaction map of proteins identified in the renal scaffold. 
process, 296 proteins were conserved to both native and kidney scaffold and 128 were exclusively represented in renal scaffold (Data Supplementary). Figure 3(B) shows the interaction network of the proteins with high confidence. The interactions among themselves indicates that the proteins are biologically connected.

GOrilla tool using a single ranked list of genes was performed to analyze the cellular component ontology in the decellularized rat kidney. The system recognized 421 genes out of 424 gene terms entered, only 419 of these genes were associated with a GO term. The results revealed $20 \mathrm{GO}$ terms enriched for cellular component (Figure 4, Table 1). Some highly enriched cellular component terms were associated to protein complex and ECM. Associated genes for extracellular matrix term (GO:0031012) are shown in the Table 2 . Each gene name is specified by gene symbol followed by a short description of the gene.

Table 1. GO classification of enriched cellular component.

\begin{tabular}{|c|c|c|c|c|c|}
\hline GO term & Ontology & Description & p-Value & $\begin{array}{c}\text { FDR } \\
\text { q-value }\end{array}$ & Enrichment \\
\hline GO:0043209 & Cellular Component & myelin sheath & $2.24 \mathrm{E}-5$ & $1.46 \mathrm{E}-2$ & 1.96 \\
\hline GO:0043234 & Cellular Component & protein complex & $4.75 \mathrm{E}-5$ & $1.55 \mathrm{E}-2$ & 2.43 \\
\hline GO:0031012 & Cellular Component & extracellular matrix & $6.79 \mathrm{E}-5$ & $1.47 \mathrm{E}-2$ & 1.91 \\
\hline GO:0030863 & Cellular Component & cortical cytoskeleton & $1.07 \mathrm{E}-4$ & $1.74 \mathrm{E}-2$ & 35.91 \\
\hline GO:0030139 & Cellular Component & endocytic vesicle & $1.3 \mathrm{E}-4$ & $1.69 \mathrm{E}-2$ & 34.92 \\
\hline GO:0098862 & Cellular Component & $\begin{array}{l}\text { cluster of actin-based cell } \\
\text { projections }\end{array}$ & $1.96 \mathrm{E}-4$ & $2.13 \mathrm{E}-2$ & 16.76 \\
\hline GO:0005903 & Cellular Component & brush border & $1.96 \mathrm{E}-4$ & $1.82 \mathrm{E}-2$ & 16.76 \\
\hline GO:0043231 & Cellular Component & $\begin{array}{c}\text { intracellular } \\
\text { membrane-bounded organelle }\end{array}$ & $2.68 \mathrm{E}-4$ & $2.18 \mathrm{E}-2$ & 1.24 \\
\hline GO:0005759 & Cellular Component & mitochondrial matrix & $2.82 \mathrm{E}-4$ & $2.04 \mathrm{E}-2$ & 1.37 \\
\hline GO:0005768 & Cellular Component & endosome & $3.59 \mathrm{E}-4$ & $2.33 \mathrm{E}-2$ & 10.07 \\
\hline GO:0044448 & Cellular Component & cell cortex part & $3.78 \mathrm{E}-4$ & $2.23 \mathrm{E}-2$ & 27.93 \\
\hline GO:0043233 & Cellular Component & organelle lumen & $4.41 \mathrm{E}-4$ & $2.39 \mathrm{E}-2$ & 1.90 \\
\hline GO:0031974 & Cellular Component & membrane-enclosed lumen & $4.41 \mathrm{E}-4$ & $2.21 \mathrm{E}-2$ & 1.90 \\
\hline GO:0005911 & Cellular Component & cell-cell junction & $5.21 \mathrm{E}-4$ & $2.42 \mathrm{E}-2$ & 13.97 \\
\hline GO:0005774 & Cellular Component & vacuolar membrane & $5.68 \mathrm{E}-4$ & $2.47 \mathrm{E}-2$ & 5.72 \\
\hline GO:0012506 & Cellular Component & vesicle membrane & $6.23 \mathrm{E}-4$ & $2.54 \mathrm{E}-2$ & 12.89 \\
\hline GO:0005739 & Cellular Component & mitochondrion & $7.2 \mathrm{E}-4$ & $2.76 \mathrm{E}-2$ & 1.31 \\
\hline GO:0098852 & Cellular Component & lytic vacuole membrane & $8.46 \mathrm{E}-4$ & $3.06 \mathrm{E}-2$ & 8.80 \\
\hline GO:0005765 & Cellular Component & lysosomal membrane & $8.46 \mathrm{E}-4$ & $2.9 \mathrm{E}-2$ & 8.80 \\
\hline GO:1990204 & Cellular Component & oxidoreductase complex & $9.09 \mathrm{E}-4$ & $2.96 \mathrm{E}-2$ & 2.54 \\
\hline
\end{tabular}


Table 2. Associated genes for extracellular matrix term (GO:0031012).

\begin{tabular}{|c|c|}
\hline Germ & Description \\
\hline Vim & vimentin \\
\hline Agrn & agrin \\
\hline Lmna & $\operatorname{lamin} \mathrm{a} / \mathrm{c}$ \\
\hline Rpn1 & ribophorin i \\
\hline Canx & calnexin \\
\hline Dynclh1 & dynein cytoplasmic 1 heavy chain 1 \\
\hline Alpl & alkaline phosphatase, liver/bone/kidney \\
\hline Eef2 & eukaryotic translation elongation factor 2 \\
\hline Hspa8 & heat shock 70 kda protein 8 \\
\hline Myh9 & myosin, heavy chain 9 , non-muscle \\
\hline Hspa9 & heat shock protein 9 \\
\hline Hsp90b1 & heat shock protein 90 , beta, member 1 \\
\hline Prdx1 & peroxiredoxin 1 \\
\hline Hspa5 & heat shock protein 5 \\
\hline Tubb5 & tubulin, beta 5 class i \\
\hline Hadha & $\begin{array}{l}\text { hydroxyacyl-coa dehydrogenase/3-ketoacyl-coa thiolase/enoyl-coa hydratase } \\
\text { (trifunctional protein), alpha subunit }\end{array}$ \\
\hline Col1a2 & collagen, type i, alpha 2 \\
\hline Nid2 & nidogen 2 (osteonidogen) \\
\hline Nid1 & nidogen 1 \\
\hline Colla1 & collagen, type i, alpha 1 \\
\hline Cltc & clathrin, heavy chain (hc) \\
\hline Clu & clusterin \\
\hline Atp5a1 & atp synthase, $h+$ transporting, mitochondrial f1 complex, alpha subunit 1 , cardiac muscle \\
\hline Hspd1 & heat shock protein 1 (chaperonin) \\
\hline Slc25a5 & $\begin{array}{l}\text { solute carrier family } 25 \\
\text { (mitochondrial carrier; adenine nucleotide translocator), member } 5\end{array}$ \\
\hline Atp5b & atp synthase, $\mathrm{h}+$ transporting, mitochondrial $\mathrm{f} 1$ complex, beta polypeptide \\
\hline Lamb2 & laminin, beta 2 \\
\hline Fn1 & fibronectin 1 \\
\hline Vcan & versican \\
\hline
\end{tabular}




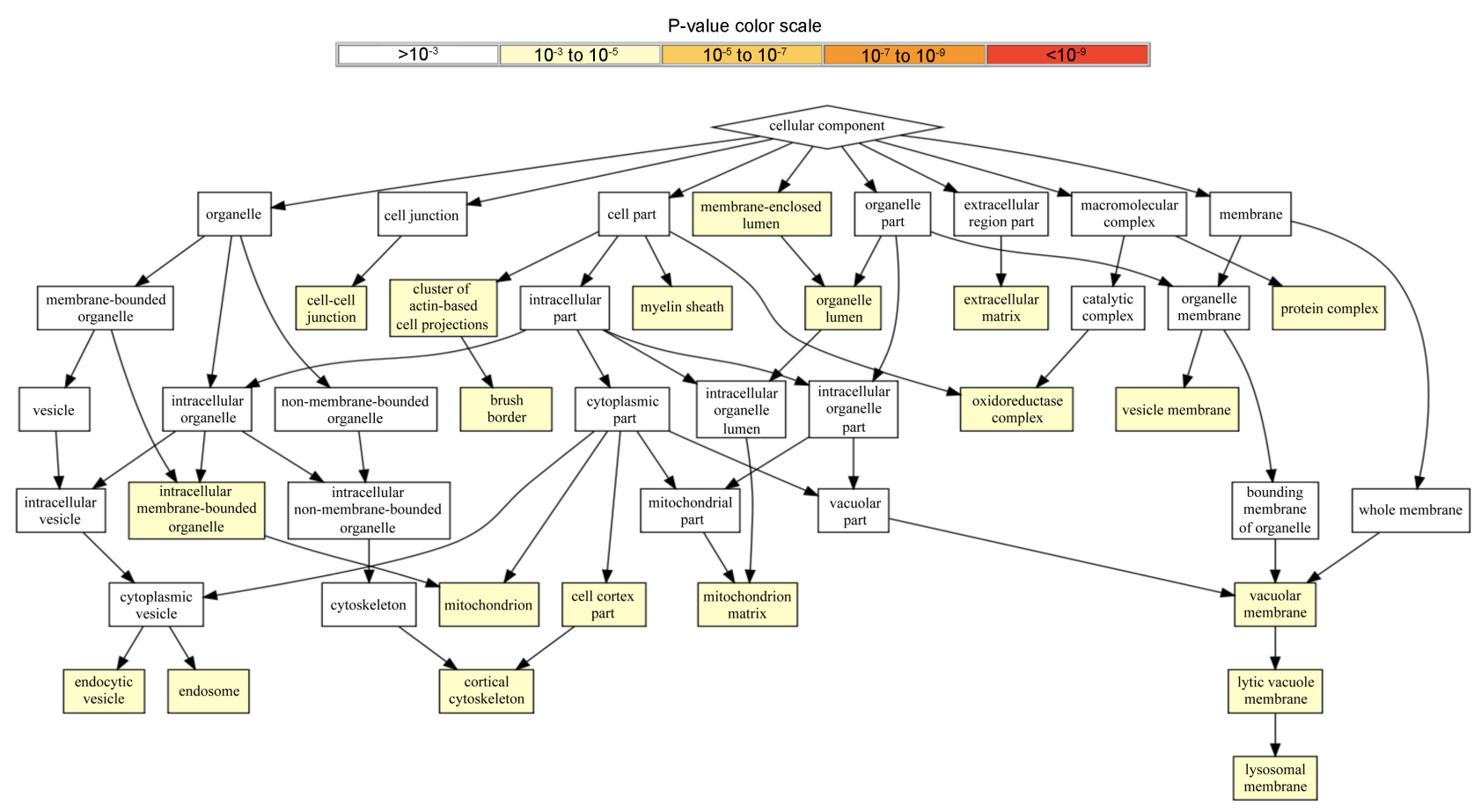

Figure 4. GO classification of enriched cellular component in renal scaffold.

Proteins were subsequently categorized into their functional and biological processes. GOrilla tool using two unranked lists of genes (scaffold as target list and native as background list) was performed. The system recognized 1404 genes out of 1414 gene terms entered, only 1092 of these genes were associated with a GO term. The results revealed $2 \mathrm{GO}$ terms enriched for molecular function (Figure 5, Table 3) and 3 GO terms enriched for biological process (Figure 6, Table 4).

The biological process terms identified were related to metabolic process including organic acid metabolic process (GO:0006082), oxoacid metabolic process (GO:0043436) and carboxylic acid metabolic process (GO:0019752). Several enrichment molecular function terms were related to cofactor binding (GO:0048037) and secondary active transmembrane transporter activity (GO:0015291).

\section{DISCUSSION}

Renal transplantation is currently the most effective treatment for ESRD that represents one of the primary mortality reason globally. Because of this, the demand for transplantable organs continues to grow and the number of available organs seems to have plateaued in recent years. Consequently, there is a urgent need to identify new, potentially inexhaustible sources of clinically applicable and transplantable kidneys.

Perfusion decellularization of whole organs is a novel approach to organ engineering and regeneration. The use of a decellularized kidney scaffold is based on the mechanical and biological property of the ECM, which can maintain natural cellular architecture and some residual molecules that may advantage recellularization, differentiation and proliferation of the host cells. Kidney decellularization has been successfully achieved using a variety of approaches and protocols. Recently, Destefani et al. showed a comprehensive investigation about different protocols for rat kidney decellularization [19]. Although, to date no specific protocol has demonstrated to be superior to the others.

In this study, the continuous perfusion decellularization protocol was based on the combination of two detergents (SDS and Triton X-100). We perfused kidneys using a peristaltic pump to ensure monitoring of perfusion pressure. Perfusion pressure was maintained in physiological range (up to 120 


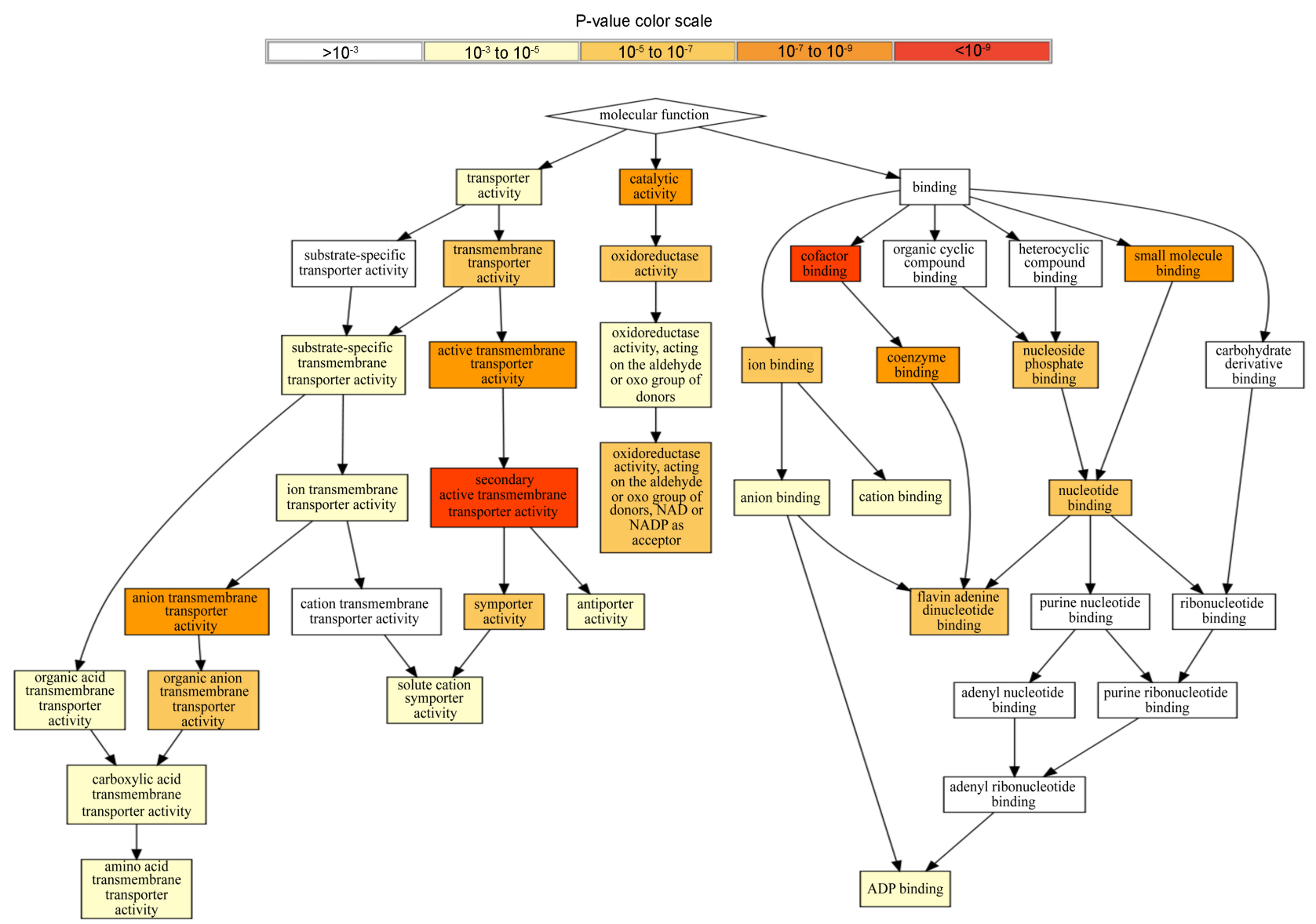

Figure 5. GO classification of enriched molecular function in renal scaffold.

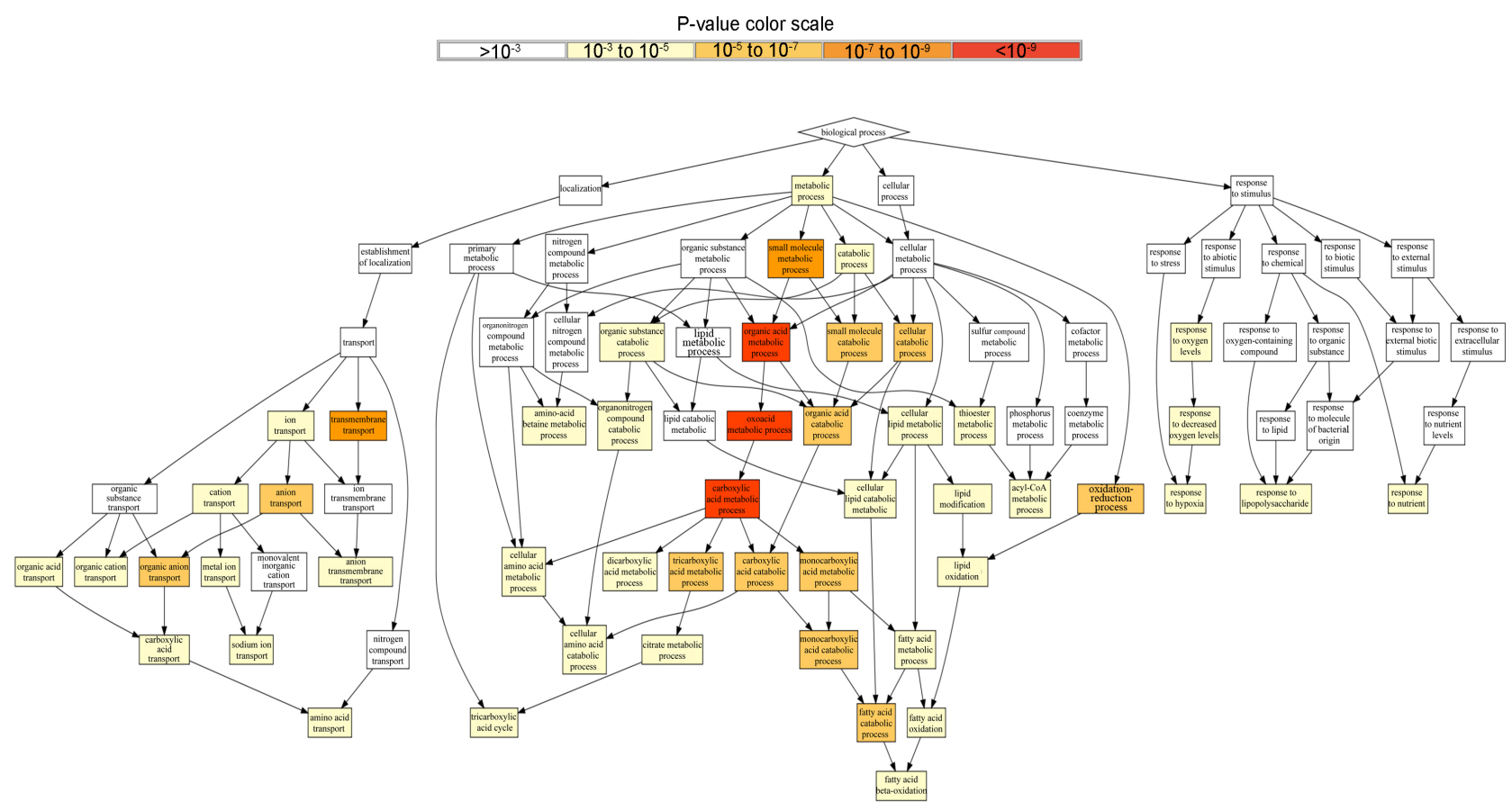

Figure 6. GO classification of enriched biological process in renal scaffold. 
Table 3. GO classification of enriched molecular function.

\begin{tabular}{|c|c|c|c|c|c|}
\hline GO term & Ontology & Description & p-Value & $\begin{array}{c}\text { FDR } \\
\text { q-value }\end{array}$ & Enrichment \\
\hline GO:0048037 & Molecular Function & cofactor binding & $1.45 \mathrm{E}-10$ & $2.61 \mathrm{E}-7$ & 1.79 \\
\hline GO:0015291 & Molecular Function & $\begin{array}{l}\text { secondary active } \\
\text { transmembrane } \\
\text { transporter activity }\end{array}$ & $5.81 \mathrm{E}-10$ & $5.24 \mathrm{E}-7$ & 2.43 \\
\hline GO:0022804 & Molecular Function & $\begin{array}{l}\text { active transmembrane } \\
\text { transporter activity }\end{array}$ & $4.61 \mathrm{E}-9$ & $2.77 \mathrm{E}-6$ & 1.99 \\
\hline GO:0036094 & Molecular Function & small molecule binding & $1.23 \mathrm{E}-8$ & $5.55 \mathrm{E}-6$ & 1.34 \\
\hline GO:0008509 & Molecular Function & $\begin{array}{l}\text { anion transmembrane } \\
\text { transporter activity }\end{array}$ & $4.43 \mathrm{E}-8$ & $1.6 \mathrm{E}-5$ & 2.26 \\
\hline GO:0003824 & Molecular Function & catalytic activity & $5.98 \mathrm{E}-8$ & $1.79 \mathrm{E}-5$ & 1.20 \\
\hline GO:0050662 & Molecular Function & coenzyme binding & $7.41 \mathrm{E}-8$ & $1.91 \mathrm{E}-5$ & 1.76 \\
\hline GO:0050660 & Molecular Function & $\begin{array}{c}\text { flavin adenine } \\
\text { dinucleotide binding }\end{array}$ & $3.07 \mathrm{E}-7$ & $6.92 \mathrm{E}-5$ & 2.29 \\
\hline GO:0008514 & Molecular Function & $\begin{array}{l}\text { organic anion transmembrane } \\
\text { transporter activity }\end{array}$ & $3.46 \mathrm{E}-7$ & $6.93 \mathrm{E}-5$ & 2.37 \\
\hline GO:0016491 & Molecular Function & oxidoreductase activity & $4.52 \mathrm{E}-7$ & $8.15 \mathrm{E}-5$ & 1.46 \\
\hline GO:1901265 & Molecular Function & nucleoside phosphate binding & $8.79 \mathrm{E}-7$ & $1.44 \mathrm{E}-4$ & 1.34 \\
\hline GO:0000166 & Molecular Function & nucleotide binding & $8.79 \mathrm{E}-7$ & $1.32 \mathrm{E}-4$ & 1.34 \\
\hline GO:0022857 & Molecular Function & $\begin{array}{l}\text { transmembrane } \\
\text { transporter activity }\end{array}$ & $9.03 \mathrm{E}-7$ & $1.25 \mathrm{E}-4$ & 1.66 \\
\hline GO:0016620 & Molecular Function & $\begin{array}{l}\text { oxidoreductase activity, } \\
\text { acting on the aldehyde or } \\
\text { oxo group of donors, NAD } \\
\text { or NADP acceptor }\end{array}$ & $1.31 \mathrm{E}-6$ & $1.68 \mathrm{E}-4$ & 2.61 \\
\hline GO:0043167 & Molecular Function & ion binding & $2.95 \mathrm{E}-6$ & $3.54 \mathrm{E}-4$ & 1.20 \\
\hline GO:0015293 & Molecular Function & symporter activity & $9.23 \mathrm{E}-6$ & $1.04 \mathrm{E}-3$ & 2.61 \\
\hline GO:0016903 & Molecular Function & $\begin{array}{l}\text { oxidoreductase activity, } \\
\text { acting on the aldehyde or } \\
\text { oxo group of donors }\end{array}$ & $1.18 \mathrm{E}-5$ & $1.25 \mathrm{E}-3$ & 2.32 \\
\hline
\end{tabular}




\section{Continued}

\begin{tabular}{|c|c|c|c|c|c|}
\hline GO:0043531 & Molecular Function & ADP binding & $3.17 \mathrm{E}-5$ & $3.17 \mathrm{E}-3$ & 2.42 \\
\hline GO:0043168 & Molecular Function & anion binding & $3.44 \mathrm{E}-5$ & $3.26 \mathrm{E}-3$ & 1.25 \\
\hline GO:0022891 & Molecular Function & $\begin{array}{c}\text { substrate-specific } \\
\text { transmembrane transporter } \\
\text { activity }\end{array}$ & $6.73 \mathrm{E}-5$ & $6.06 \mathrm{E}-3$ & 1.56 \\
\hline GO:0015075 & Molecular Function & $\begin{array}{l}\text { ion transmembrane } \\
\text { transporter activity }\end{array}$ & $1.16 \mathrm{E}-4$ & $9.92 \mathrm{E}-3$ & 1.55 \\
\hline GO:0005342 & Molecular Function & $\begin{array}{l}\text { organic acid transmembrane } \\
\text { transporter activity }\end{array}$ & $1.55 \mathrm{E}-4$ & $1.27 \mathrm{E}-2$ & 2.26 \\
\hline GO:0015171 & Molecular Function & $\begin{array}{l}\text { amino acid transmembrane } \\
\text { transporter activity }\end{array}$ & $4.51 \mathrm{E}-4$ & $3.53 \mathrm{E}-2$ & 2.61 \\
\hline GO:0015294 & Molecular Function & $\begin{array}{c}\text { solute:cation symporter } \\
\text { activity }\end{array}$ & $4.51 \mathrm{E}-4$ & $3.38 \mathrm{E}-2$ & 2.61 \\
\hline GO:0005215 & Molecular Function & transporter activity & $6.09 \mathrm{E}-4$ & $4.39 \mathrm{E}-2$ & 1.37 \\
\hline GO:0015297 & Molecular Function & antiporter activity & $8.17 \mathrm{E}-4$ & $5.66 \mathrm{E}-2$ & 2.21 \\
\hline GO:0046943 & Molecular Function & $\begin{array}{l}\text { carboxylic acid } \\
\text { transmembrane } \\
\text { transporter activity }\end{array}$ & $8.17 \mathrm{E}-4$ & $5.45 \mathrm{E}-2$ & 2.21 \\
\hline GO:0043169 & Molecular Function & cation binding & $9.23 \mathrm{E}-4$ & $5.94 \mathrm{E}-2$ & 1.22 \\
\hline
\end{tabular}

$\mathrm{mmHg}$ ) during the entire duration of the decellularization process. This approach differs from the gravity-based perfusion system adopted by Guyette J et al. [11]. Moreover, we decided to use a lower concentration of SDS (0.66\%), because high concentrations of SDS can lead to the destruction of the ECM [20-22]. Histological data showed that our decellularization procedure was effective in maintaining kidney microarchitecture. Furthermore, even the integrity of the basal membrane is preserved, which is a basic requirement for successful endothelialization of the vessels [23]. Recellularization process requires not only the preservation of the overall architectural integrity of the organ but the maintenance of a vascular network intact, both are indispensable for ensuring adequate oxygenation of the organ. Taking this into consideration, we demostrated that the vascular tree was preserved after the decellularization process, which was evidenced by perfusion through renal artery of blue colored solution.

In this research, we employed a proteomics approach (by LC-MS/MS) to generate a comprehensive protein expression profile of kidney scaffold. As expected, fewer distinct proteins were detected after decellularization process. We identified 424 proteins in the kidney scaffold of which 296 proteins were conserved to both native and kidney scaffold. In the decellularized kidney scaffold, we identified a large number of both remnant cellular and ECM proteins. During creation of a decellularized scaffold, it is crucial to preserve the organ-specific ECM "zip codes" that support site appropriate cell attachment and differentiation $[15,24]$. The identification of acellular matrix composition by LC-MS/MS confirms the expression of the main components of ECM including collagen type I, laminin, fibronectin, vimentin and 
Table 4. GO classification of enriched biological process.

\begin{tabular}{|c|c|c|c|c|c|}
\hline GO term & Ontology & Description & p-Value & $\begin{array}{c}\text { FDR } \\
\text { q-value }\end{array}$ & Enrichment \\
\hline GO:0006082 & Biologycal Process & $\begin{array}{c}\text { organic acid } \\
\text { metabolic process }\end{array}$ & $5.18 \mathrm{E}-12$ & $3.71 \mathrm{E}-8$ & 1.56 \\
\hline GO:0043436 & Biologycal Process & $\begin{array}{c}\text { oxoacid metabolic } \\
\text { process }\end{array}$ & $1.79 \mathrm{E}-11$ & $6.43 \mathrm{E}-8$ & 1.55 \\
\hline GO:0019752 & Biologycal Process & $\begin{array}{c}\text { carboxylic acid } \\
\text { metabolic process }\end{array}$ & $6.09 \mathrm{E}-11$ & $1.45 \mathrm{E}-7$ & 1.54 \\
\hline GO:0044281 & Biologycal Process & $\begin{array}{l}\text { small molecule } \\
\text { metabolic process }\end{array}$ & $2.78 \mathrm{E}-8$ & $4.98 \mathrm{E}-5$ & 1.34 \\
\hline GO:0055085 & Biologycal Process & transmembrane transport & $8.63 \mathrm{E}-8$ & $1.24 \mathrm{E}-4$ & 1.67 \\
\hline GO:0055114 & Biologycal Process & $\begin{array}{l}\text { oxidation-reduction } \\
\text { process }\end{array}$ & $1.06 \mathrm{E}-7$ & $1.26 \mathrm{E}-4$ & 1.46 \\
\hline GO:0016054 & Biologycal Process & $\begin{array}{c}\text { organic acid catabolic } \\
\text { process }\end{array}$ & $1.34 \mathrm{E}-7$ & $1.37 \mathrm{E}-4$ & 1.76 \\
\hline GO:0046395 & Biologycal Process & $\begin{array}{c}\text { carboxylic acid } \\
\text { catabolic process }\end{array}$ & $1.34 \mathrm{E}-7$ & $1.2 \mathrm{E}-4$ & 1.76 \\
\hline GO:0006820 & Biologycal Process & anion transport & $2.4 \mathrm{E}-7$ & $1.91 \mathrm{E}-4$ & 1.88 \\
\hline GO:0072329 & Biologycal Process & $\begin{array}{l}\text { monocarboxylic acid } \\
\text { catabolic process }\end{array}$ & $5.39 \mathrm{E}-7$ & $3.86 \mathrm{E}-4$ & 2.04 \\
\hline GO:0072350 & Biologycal Process & $\begin{array}{l}\text { tricarboxylic acid } \\
\text { metabolic process }\end{array}$ & $7.28 \mathrm{E}-7$ & $4.74 \mathrm{E}-4$ & 2.28 \\
\hline GO:0032787 & Biologycal Process & $\begin{array}{l}\text { monocarboxylic acid } \\
\text { metabolic process }\end{array}$ & $1.15 \mathrm{E}-6$ & $6.88 \mathrm{E}-4$ & 1.57 \\
\hline GO:0044282 & Biologycal Process & $\begin{array}{l}\text { small molecule } \\
\text { catabolic process }\end{array}$ & $1.51 \mathrm{E}-6$ & $8.31 \mathrm{E}-4$ & 1.62 \\
\hline GO:0009062 & Biologycal Process & $\begin{array}{c}\text { fatty acid catabolic } \\
\text { process }\end{array}$ & $1.85 \mathrm{E}-6$ & $9.47 \mathrm{E}-4$ & 2.05 \\
\hline GO:0015711 & Biologycal Process & organic anion transport & $5.62 \mathrm{E}-6$ & $2.68 \mathrm{E}-3$ & 1.85 \\
\hline GO:0044248 & Biologycal Process & cellular catabolic process & $8.25 \mathrm{E}-6$ & $3.69 \mathrm{E}-3$ & 1.36 \\
\hline
\end{tabular}




\section{Continued}

\begin{tabular}{|c|c|c|c|c|c|}
\hline GO:0006635 & Biologycal Process & fatty acid beta-oxidation & $1.35 \mathrm{E}-5$ & $5.7 \mathrm{E}-3$ & 2.05 \\
\hline GO:0009056 & Biologycal Process & catabolic process & $1.72 \mathrm{E}-5$ & $6.84 \mathrm{E}-3$ & 1.31 \\
\hline GO:0006099 & Biologycal Process & tricarboxylic acid cycle & $2.13 \mathrm{E}-5$ & $8.04 \mathrm{E}-3$ & 2.22 \\
\hline GO:0006101 & Biologycal Process & citrate metabolic process & $2.13 \mathrm{E}-5$ & $7.64 \mathrm{E}-3$ & 2.22 \\
\hline GO:0034440 & Biologycal Process & lipid oxidation & $2.16 \mathrm{E}-5$ & $7.35 \mathrm{E}-3$ & 1.95 \\
\hline GO:0019395 & Biologycal Process & fatty acid oxidation & $2.16 \mathrm{E}-5$ & $7.02 \mathrm{E}-3$ & 1.95 \\
\hline GO:0006577 & Biologycal Process & $\begin{array}{l}\text { amino-acid betaine } \\
\text { metabolic process }\end{array}$ & $2.45 \mathrm{E}-5$ & $7.61 \mathrm{E}-3$ & 2.61 \\
\hline GO:0006811 & Biologycal Process & ion transport & $2.99 \mathrm{E}-5$ & $8.92 \mathrm{E}-3$ & 1.46 \\
\hline GO:0015849 & Biologycal Process & organic acid transport & $3.62 \mathrm{E}-5$ & $1.04 \mathrm{E}-2$ & 1.98 \\
\hline GO:1901565 & Biologycal Process & $\begin{array}{c}\text { organonitrogen } \\
\text { compound catabolic } \\
\text { process }\end{array}$ & $3.86 \mathrm{E}-5$ & $1.06 \mathrm{E}-2$ & 1.50 \\
\hline GO:1901575 & Biologycal Process & $\begin{array}{l}\text { organic substance } \\
\text { catabolic process }\end{array}$ & $4.41 \mathrm{E}-5$ & $1.17 \mathrm{E}-2$ & 1.33 \\
\hline GO:0098656 & Biologycal Process & $\begin{array}{c}\text { anion transmembrane } \\
\text { transport }\end{array}$ & $4.86 \mathrm{E}-5$ & $1.24 \mathrm{E}-2$ & 2.19 \\
\hline GO:0030258 & Biologycal Process & lipid modification & $5.78 \mathrm{E}-5$ & $1.43 \mathrm{E}-2$ & 1.86 \\
\hline GO:0046942 & Biologycal Process & carboxylic acid transport & $7.41 \mathrm{E}-5$ & $1.77 \mathrm{E}-2$ & 1.95 \\
\hline GO:0044242 & Biologycal Process & $\begin{array}{c}\text { cellular lipid catabolic } \\
\text { process }\end{array}$ & $7.86 \mathrm{E}-5$ & $1.82 \mathrm{E}-2$ & 1.76 \\
\hline GO:0070482 & Biologycal Process & response to oxygen levels & $1.46 \mathrm{E}-4$ & $3.27 \mathrm{E}-2$ & 1.61 \\
\hline GO:0006865 & Biologycal Process & amino acid transport & $1.71 \mathrm{E}-4$ & $3.71 \mathrm{E}-2$ & 2.61 \\
\hline GO:0006814 & Biologycal Process & sodium ion transport & $1.92 \mathrm{E}-4$ & $4.04 \mathrm{E}-2$ & 2.39 \\
\hline GO:0030001 & Biologycal Process & metal ion transport & $2.43 \mathrm{E}-4$ & $4.97 \mathrm{E}-2$ & 1.76 \\
\hline GO:0043648 & Biologycal Process & $\begin{array}{l}\text { dicarboxylic acid } \\
\text { metabolic process }\end{array}$ & $2.61 \mathrm{E}-4$ & $5.2 \mathrm{E}-2$ & 1.72 \\
\hline GO:0036293 & Biologycal Process & $\begin{array}{l}\text { response to decreased } \\
\text { oxygen levels }\end{array}$ & $2.64 \mathrm{E}-4$ & $5.11 \mathrm{E}-2$ & 1.62 \\
\hline
\end{tabular}




\section{Continued}

\begin{tabular}{|c|c|c|c|c|c|}
\hline GO:0006631 & Biologycal Process & $\begin{array}{c}\text { fatty acid metabolic } \\
\text { process }\end{array}$ & $3.68 \mathrm{E}-4$ & $6.93 \mathrm{E}-2$ & 1.55 \\
\hline GO:0006520 & Biologycal Process & $\begin{array}{l}\text { cellular amino acid } \\
\text { metabolic process }\end{array}$ & $4.15 \mathrm{E}-4$ & $7.63 \mathrm{E}-2$ & 1.49 \\
\hline GO:0044255 & Biologycal Process & $\begin{array}{c}\text { cellular lipid } \\
\text { metabolic process }\end{array}$ & $4.23 \mathrm{E}-4$ & $7.58 \mathrm{E}-2$ & 1.42 \\
\hline GO:0001666 & Biologycal Process & response to hypoxia & $4.49 \mathrm{E}-4$ & $7.84 \mathrm{E}-2$ & 1.60 \\
\hline GO:0015695 & Biologycal Process & organic cation transport & $4.51 \mathrm{E}-4$ & $7.69 \mathrm{E}-2$ & 2.61 \\
\hline GO:0008152 & Biologycal Process & metabolic process & $4.53 \mathrm{E}-4$ & $7.55 \mathrm{E}-2$ & 1.10 \\
\hline GO:0009063 & Biologycal Process & $\begin{array}{l}\text { cellular amino acid } \\
\text { catabolic process }\end{array}$ & $4.67 \mathrm{E}-4$ & $7.61 \mathrm{E}-2$ & 1.69 \\
\hline GO:0007584 & Biologycal Process & response to nutrient & $6.79 \mathrm{E}-4$ & $1.08 \mathrm{E}-1$ & 1.55 \\
\hline GO:0032496 & Biologycal Process & $\begin{array}{c}\text { response to } \\
\text { lipopolysaccharide }\end{array}$ & $7.83 \mathrm{E}-4$ & $1.22 \mathrm{E}-1$ & 1.74 \\
\hline GO:0006637 & Biologycal Process & $\begin{array}{c}\text { acyl-CoA metabolic } \\
\text { process }\end{array}$ & $8.8 \mathrm{E}-4$ & $1.34 \mathrm{E}-1$ & 1.95 \\
\hline GO:0035383 & Biologycal Process & $\begin{array}{c}\text { thioester metabolic } \\
\text { process }\end{array}$ & $8.8 \mathrm{E}-4$ & $1.31 \mathrm{E}-1$ & 1.95 \\
\hline GO:0006812 & Biologycal Process & cation transport & $9.52 \mathrm{E}-4$ & $1.39 \mathrm{E}-1$ & 1.46 \\
\hline
\end{tabular}

nidogen, among others.

Currently, the few published reports of proteome composition of decellularized biological scaffolds focus primarily on ECM proteins [15, 25-27]. In this work, along with ECM proteins, we identified numerous cellular proteins mainly related to metabolic processes, in binding and transporter activity. Interestingly, we identified proteins involved in kidney development (Slc34a1, Aqp1, Mme, Podxl, Sdc4, Nphs2, Hspa4, Cat, Hrsp12, Cyp4a8, Asl, Aldh1a1, Aldh9a1, Acat1, Ass1). Particularly, Podxl, Aqp1 and Nphs2 are involved in kidney epithelium development and glomerulus development. Specifically, Podxl play an essential role in the formation and maintenance of podocyte foot processes [28] and Podxl-deficiency prevents renal tubule formation [29].

\section{CONCLUSION}

Collectively, our data reveal that decellularized kidney scaffold retain characteristic cues from local microenvironment that could be the basis for specific homing and celular differentation in the recellularization process. Thus, we assume that the goal of decellularization is to identify the crucial proteins that must remain within the biological scaffolds in order to complete a successful recellularization process. 


\section{ACKNOWLEDGEMENTS}

The authors are grateful to Dr. Ignacio Ortea from IMIBIC Proteomics Unit and M. J. Jimenez for their technical assistance.

\section{REFERENCES}

1. Schoolwerth, A.C., Engelgau, M.M., Hostetter, T.H., Rufo, K.H., Chianchiano, D., McClellan, W.M., et al. (2006) Chronic Kidney Disease: A Public Health Problem That Needs a Public Health Action Plan. Preventing Chronic Disease, 3, A57.

2. Schieppati, A. and Remuzzi, G. (2005) Chronic Renal Diseases as a Public Health Problem: Epidemiology, Social, and Economic Implications. Kidney International Supplements, 98, S7-S10.

https://doi.org/10.1111/j.1523-1755.2005.09801.x

3. Meguid El Nahas, A. and Bello, A.K. (2005) Chronic Kidney Disease: The Global Challenge. Lancet, 365, 331-340. https://doi.org/10.1016/S0140-6736(05)17789-7

4. Abolbashari, M., Agcaoili, S.M., Lee, M.K., Ko, I.K., Aboushwareb, T., Jackson, J.D., et al. (2016) Repopulation of Porcine Kidney Scaffold Using Porcine Primary Renal Cells. Acta Biomater, 29, 52-61. https://doi.org/10.1016/j.actbio.2015.11.026

5. Ott, H.C., Matthiesen, T.S., Goh, S.K., Black, L.D., Kren, S.M., Netoff, T.I., et al. (2008) Perfusion-Decellularized Matrix: Using Nature's Platform to Engineer a Bioartificial Heart. Nature Medicine, 14, 213-221. https://doi.org/10.1038/nm1684

6. Ott, H.C., Clippinger, B., Conrad, C., Schuetz, C., Pomerantseva, I., Ikonomou, L., et al. (2010) Regeneration and Orthotopic Transplantation of a Bioartificial Lung. Nature Medicine, 16, 927-933. https://doi.org/10.1038/nm.2193

7. Uygun, B.E., Soto-Gutierrez, A., Yagi, H., Izamis, M.L., Guzzardi, M.A., Shulman, C., et al. (2010) Organ Reengineering through Development of a Transplantable Recellularized Liver Graft Using Decellularized Liver Matrix. Nature Medicine, 16, 814-820. https://doi.org/10.1038/nm.2170

8. Baptista, P.M., Siddiqui, M.M., Lozier, G., Rodriguez, S.R., Atala, A. and Soker, S. (2011) The Use of Whole Organ Decellularization for the Generation of a Vascularized Liver Organoid. Hepatology, 53, 604-617. https://doi.org/10.1002/hep.24067

9. Orlando, G., Wood, K.J., Stratta, R.J., Yoo, J.J., Atala, A. and Soker. S. (2011) Regenerative Medicine and Organ Transplantation: Past, Present, and Future. Transplantation, 91, 1310-1317. https://doi.org/10.1097/TP.0b013e318219ebb5

10. Chani, B, Puri, V., Sobti, R.C., Jha, V. and Puri, S. (2017) Decellularized Scaffold of Cryopreserved Rat Kidney Retains Its Recellularization Potential. PLoS One, 12, e0173040. https://doi.org/10.1371/journal.pone.0173040

11. Guyette, J.P., Gilpin, S.E., Charest, J.M., Tapias, L.F., Ren, X. and Ott, H.C. (2014) Perfusion Decellularization of Whole Organs. Nature Protocols, 9, 1451-1468. https://doi.org/10.1038/nprot.2014.097

12. Peloso, A., Ferrario, J., Maiga, B., Benzoni, I., Bianco, C., Citro, A., et al. (2015) Creation and Implantation of Acellular Rat Renal ECM-Based Scaffolds. Organogenesis, 11, 58-74.

https://doi.org/10.1080/15476278.2015.1072661

13. Song, J.J., Guyette, J.P., Gilpin, S.E., Gonzalez, G., Vacanti, J.P. and Ott, H.C. (2013) Regeneration and Experimental Orthotopic Transplantation of a Bioengineered Kidney. Nature Medicine, 19, 646-651.

https://doi.org/10.1038/nm.3154

14. Caralt, M., Uzarski, J.S., Iacob, S., Obergfell, K.P, Berg, N., Bijonowski, B.M., et al. (2015) Optimization and Critical Evaluation of Decellularization Strategies to Develop Renal Extracellular Matrix Scaffolds as Biological Templates for Organ Engineering and Transplantation. American Journal of Transplantation, 15, 64-75. 


\section{https://doi.org/10.1111/ajt.12999}

15. Li, Q., Uygun, B.E., Geerts, S., Oze, S., Scalf, M., Gilpin, S.E., et al. (2016) Proteomic Analysis of Naturally-Sourced Biological Scaffolds. Biomaterials, 75, 37-46. https://doi.org/10.1016/j.biomaterials.2015.10.011

16. Rusconi, F., Valton, E., Nguyen, R. and Dufourc, E. (2001) Quantification of Sodium Dodecyl Sulfate in Microliter-Volume Biochemical Samples by Visible Light Spectroscopy. Analytical Biochemistry, 295, 31-37. https://doi.org/10.1006/abio.2001.5164

17. Vowinckel, J., Capuano, F., Campbell, K., Deery, M.J., Lilley, K.S. and Ralser, M. (2013) The Beauty of Being (label)-Free: Sample Preparation Methods for SWATH-MS and Next-Generation Targeted Proteomics. F1000Research, 2, 272. https://doi.org/10.12688/f1000research.2-272.v2

18. Wang, Y., Bao, J., Wu, Q., Zhou, Y., Li, Y., Wu, X., et al. (2015) Method for Perfusion Decellularization of Porcine Whole Liver and Kidney for Use as a Scaffold for Clinical-Scale Bioengineering Engrafts. Xenotransplantation, 22, 48-61. https://doi.org/10.1111/xen.12141

19. Destefani, A.C., Sirtoli, G.M. and Nogueira, B.V. (2017) Advances in the Knowledge about Kidney Decellularization and Repopulation. Frontiers in Bioengineering and Biotechnology, 5, 34. https://doi.org/10.3389/fbioe.2017.00034

20. Samouillan, V., Dandurand-Lods, J., Lamure, A., Maurel, E, Lacabanne, C., Gerosa, G., et al. (1999) Thermal Analysis Characterization of Aortic Tissues for Cardiac Valve Bioprostheses. Journal of Biomedical Materials Research, 46, 531-538. https://doi.org/10.1002/(SICI)1097-4636(19990915)46:4<531::AID-JBM11>3.0.CO;2-2

21. Woods, T. and Gratzer, P.F. (2005) Effectiveness of Three Extraction Techniques in the Development of a Decellularized Bone-Anterior Cruciate Ligament-Bone Graft. Biomaterials, 26, 7339-7349. https://doi.org/10.1016/j.biomaterials.2005.05.066

22. Ren, H., Shi, X., Tao, L., Xiao, J., Han, B., Zhang, Y., et al. (2013) Evaluation of Two Decellularization Methods in the Development of a Whole-Organ Decellularized Rat Liver Scaffold. Liver International, 33, 448-458. https://doi.org/10.1111/liv.12088

23. Ross, E.A., Williams, M.J., Hamazaki, T., Terada, N., Clapp, W.L., Adin, C., et al. (2009) Embryonic Stem Cells Proliferate and Differentiate When Seeded into Kidney Scaffolds. Journal of the American Society of Nephrology, 20, 2338-2347. https://doi.org/10.1681/ASN.2008111196

24. Crapo, P.M., Gilbert, T.W. and Badylak, S.F. (2011) An Overview of Tissue and Whole Organ Decellularization Processes. Biomaterials, 32, 3233-3243. https://doi.org/10.1016/j.biomaterials.2011.01.057

25. Gilpin, S.E., Guyette, J.P., Gonzalez, G., Ren, X., Asara, J.M., Mathisen, D.J., et al. (2014) Perfusion Decellularization of Human and Porcine Lungs: Bringing the Matrix to Clinical Scale. The Journal of Heart and Lung Transplantation, 33, 298-308. https://doi.org/10.1016/j.healun.2013.10.030

26. Marçal, H., Ahmed, T., Badylak, S.F., Tottey, S. and Foster, L.J. (2012) A Comprehensive Protein Expression Profile of Extracellular Matrix Biomaterial Derived from Porcine Urinary Bladder. Regenerative Medicine, 7, 159-166. https://doi.org/10.2217/rme.12.6

27. Hill, R.C., Calle, E.A., Dzieciatkowska, M., Niklason, L.E. and Hansen, K.C. (2015) Quantification of Extracellular Matrix Proteins from a Rat Lung Scaffold to Provide a Molecular Readout for Tissue Engineering. Molecular \& Cellular Proteomics, 14, 961-973. https://doi.org/10.1074/mcp.M114.045260

28. Doyonnas, R., Kershaw, D.B., Duhme, C., Merkens, H., Chelliah, S., Graf, T., et al. (2001) Anuria, Omphalocele, and Perinatal Lethality in Mice Lacking the CD34-Related Protein Podocalyxin. The Journal of Experimental Medicine, 194, 13-27. https://doi.org/10.1084/jem.194.1.13

29. Cheng, H.Y., Lin, Y.Y., Yu, C.Y., Chen, J.Y., Shen, K.F., Lin, W.L., et al. (2005) Molecular Identification of Ca- 
nine Podocalyxin-Like Protein 1 as a Renal Tubulogenic Regulator. Journal of the American Society of Nephrology, 16, 1612-1622. https://doi.org/10.1681/ASN.2004121145

\section{SUPPLEMENTARY INFORMATION IS AVAILABLE AT:}

https://1drv.ms/x/s!AGhdhjFEC73rg1Y 